July 2021

\title{
The Intentionality of Confronting Racism, Systemic Oppression, and Cyclical Trauma in Counselor Education: A Self Study
}

\author{
Kara leva \\ Rowan University \\ Michael D. Hannon \\ Montclair State University \\ Linwood G. Vereen \\ Shippensburg University
}

Follow this and additional works at: https://trace.tennessee.edu/tsc

Part of the Counselor Education Commons

\section{Recommended Citation \\ leva, Kara; Hannon, Michael D.; and Vereen, Linwood G. (2021) "The Intentionality of Confronting Racism, Systemic Oppression, and Cyclical Trauma in Counselor Education: A Self Study," Teaching and Supervision in Counseling: Vol. 3 : Iss. 2 , Article 11. \\ https://doi.org/10.7290/tsc030211 \\ Available at: https://trace.tennessee.edu/tsc/vol3/iss2/11 \\ This article is brought to you freely and openly by Volunteer, Open-access, Library-hosted Journals (VOL Journals), published in partnership with The University of Tennessee (UT) University Libraries. This article has been accepted for inclusion in Teaching and Supervision in Counseling by an authorized editor. For more information, please visit https://trace.tennessee.edu/tsc.}




\title{
The Intentionality of Confronting Racism, Systemic Oppression, and Cyclical Trauma in Counselor Education: A Self Study
}

\author{
Kara P Ieva, Michael D Hannon, Linwood G Vereen
}

Using self-study methodology, the researchers sought to understand their practices in developing school counselors and counselor educators who acknowledge and resist anti-Black racism and marginalization to prevent harm through complacency. Given counselor education's existence as overwhelmingly White and Eurocentric, the authors investigate disrupting the heteronormative structures inherent in counseling and the academy with the prioritizing of race, systemic inequities, and cyclical trauma in their faculty roles (e.g., teaching, supervising, and service) in efforts to shift a profession slow to address society's ever-changing mental health needs. The team of counselor educators from different states in the northeast use a thematic analysis to highlight their challenges and successes at each institution and within the broader counselor education and academic context.

Keywords: self-study, counselor education, social justice counseling, decolonizing, racism

Counselor education is viewed as a progressive profession that is evolving to meet the needs of current society (American Counseling Association, 2014). This occurs in stark contrast to life and world experiences that provide differing results. As an example, the past year, 2020, presents a stark contrast in what we aspire to as a helping profession and what we actually do in terms of action. In no short order, we as counselor educators and supervisors through our professional associations have discussed how we can grow, evolve, and meet the needs of graduate students and clients who are all living in the trauma of a global pandemic. We have, at the same time, evidenced that we have growth edges to address. The rising need for professional counselors to work with clients via the variety of telemental health options provides evidence that as a profession we were not prepared. We were not prepared to deliver our curriculum to now include telemental health in the school and mental health settings. As we reflect on our systemic level of preparedness, we must also engage in reflection regarding how we as a profession will address the rise of racial injustice and civil inequality. First, we must ask ourselves what we have done to address these facts of existence. Second, we must then assess its level of impact and effectiveness. Third, we are tasked to develop a plan of action and engagement that will result in measurable outcomes that positively impact families, schools, and communities.

Counselor education is a noble profession grounded in forces of counseling that historically address the needs of those we help. We purport to be grounded in the psychodynamic, cognitive behavioral, humanistic, multicultural, and social justice paradigms while additionally espousing postmodern ways of helping. The question that we have yet to fully answer is, Do these paradigms meet the needs of our clients? Prior to this, we must ask ourselves if our methods of teaching and engagement best prepare individuals to be counselors, supervisors, and counselor educators who are anti-racist. This question then begs the question of do we engage in education and training in a manner that helps develop anti-racist professional counselors, school counselors, supervisors, and counselor educators. In contrast, we as a profession must explore the ways in which we disrupt or perpetuate racist actions. Here is 
where exploration of self as an educator is valuable and important to the growth of the profession. Racism in higher education is not new or unknown. As such, it stands to reason that racism in counselor education is a fact of existence to be explored, studied, and disrupted.

\section{Theoretical Framework: Critical Race Ecological Systems Theory}

We come to this self-study through the intersection of critical race theory (CRT; Bell, 1995) and ecological systems theory (EST; Bronfenbrenner, 1979, 2001, 2005; Bronfenbrenner \& Evans, 2000). CRT forms an interpretive framework developed by legal scholars of Color to address issues of social justice and racial oppression in society (Crenshaw et al., 1995; Delgado, 1995; Hannon et al., 2019; Nadrich, 2019). This is the lens by which we view and analyze, as race and racism are central to the study of communities of Color. Additionally, race impacts outcomes based on systemic oppression in multiple interconnecting domains (e.g., education, justice, housing, health care) influenced by governmental policies (Villalpando, 2003). EST provides a framework to inform how systems work in tandem to support or hinder individuals and communities. EST further provides a lens to understand how human development is influenced at diverse environmental and interconnected systemic levels (microsystem, mesosystem, exosystem, macrosystem, and chronosystem) throughout the life span (Brofenbrenner, 2005). CRT, as the lens through which exploration operates, allows us to then be better prepared to uncover and then take action regarding the overall influence on individuals and communities. As researchers, we work in developing preservice counselors and counselor educators in the higher education setting, who interact with the development of children and adolescents in schools and agencies that may cycle back to a higher education setting. Therefore, EST provides a structure that informs societal and environmental experiences and transitions are shaped by direct interactions with systems (Becker \& Todd, 2018; Bronfenbrenner \& Evans, 2000). These impact a person from childhood to adulthood and are made up of the dominant social norms and values that dictate the structure, policies, and laws of what is acceptable discourse in the broader social context (Bronfenbrenner, 2005). Using the intersection of EST and CRT allows us to focus on the foundation of the dominant culture that dictates the inner workings of the educational system that have long-standing impact on children, adults, and communities of Color. In this study, we explore our intentionality in disrupting the systemic racism in our own educational systems.

\section{Counselor Educators}

Counselor educators operate in a system that notably perpetuates systemic racism. According to Yancy-Bragg (2020) and her interviewees, systemic racism, also referred to as structural or institutional racism, refers to systems and structures that have procedures and processes that disadvantage Black, Indigenous, people of Color (NAACP President Derrick Johnson), where the complex interaction of culture, policy, and institutions oppress and promote the process of white supremacy (Glen Harris, president of Race Forward). Additionally, counselor educators train counselors who might work in similarly oppressive systems. Further, counselor education curricula are founded on White norms stemming from a Eurocentric frame of reference with $61.9 \%$ of counselors identifying as White (non-Hispanic), the most dominant race or ethnicity in the profession, in contrast to the $19.4 \%$ Black (non-Hispanic) counselors (U.S. Census Bureau, 2018).

While counselors have the potential to support racial healing and engagement (Ieva et al., 2021), they also have the capacity and power to perpetuate racism, white supremacy, and cultural destruction (Steen et al., n.d.). Hence, lack of intentionality in naming racism and white supremacy as hinderances is a humanistic afront. Our profession requires consistent attention to and examination of the curricula, assessments, policies, and faculty dispositions and lack of centering race as being central to existence. Additionally, attention to oppression and anti-Blackness can lead to cyclical complacency and furthering trauma for counselor educators (Cooke, 2019). Cyclical academic trauma can occur as the result of a series of microaggressions, oppression, and racism, to name a few. This, in turn, impacts counselor educators-in- 
training, preservice counselors, and the clients they serve.

Our attraction to this work stems from years of conversations in person at professional conferences and via phone calls and emails that focused on how to self-reflect and maintain accountability in a highly politicized field steeped in white norms, in academia, coupled with the stigma of mental health and counseling in society. Our professional introduction to self-study at the American Educational Research Association's annual conference (Morettini et al., 2018) provided an opportunity to learn more about this methodology and its potential usefulness in counselor education. Collectively, it allowed us the space to explore our roles of privilege, complacency, and intentionality and implement a self-study to answer our research question: What happens when we intentionally infuse the topics of race, systemic oppression, and cyclical trauma with colleagues and students during teaching, supervising, and engaging in service?

\section{Positionality}

\section{Methodology}

We are three counselor educators who are fulltime faculty with extensive experience in counseling, supervision, counseling service, and counseling research. Additionally, we have numerous intersecting and historically minoritized identities within and outside of our roles as full-time counselor educators. The first author identifies as a cisgender female, $\mathrm{LGBTQ}^{+}$, mom of two neurodiverse children, educator (P-12 and higher education), and counselor, who is White and on a constant journey of reconciling and utilizing privilege. The second author is a Black, straight, cisgender married man, with two adolescent children who have had normative and unique developmental and mental health challenges. The third author is a Black cisgender heterosexual man with five children who are all biracial. We are actively engaged in service at our respective institutions and to the counseling profession through regional and national elected and appointed positions. Finally, we describe ourselves as committed to justice, particularly in counseling and counselor education. This is evidenced by paying close attention to and taking action against processes and organizational routines that continue to marginalize counseling students and counselor educators through our teaching and institutional and professional service and in our research. Jointly, we acknowledge that racism, systemic inequities, and cyclic trauma are akin to faculty roles.

Our purpose is rooted in the opportunity to use the self-study methodology to address how we reconcile our roles in confronting and disrupting various forms of racism and oppression that we observe in our respective social locations (e.g., as Black, White, Queer) in counselor education. Selfstudy lends itself to this task as it serves simultaneously to better understand our practice in developing critical thinking, empathic understanding, socially just practices, and actionoriented counselors and counselor educators. In addition, we explore the tension resulting from intentionally teaching for social justice (Picower, 2012; Reyes et al., 2021) through an anti-racist lens and working within a field that perpetuates compliance in systemic racism. Furthermore, the self-study methodology requires us to be reflexive in our practice to become better counselor educators. About teacher reflexivity, Hannon (2019, p. 744) wrote:

Lastly, reflexivity refers to teachers' abilities to not only see themselves and their lenses but engage in patterns of behavior that require them to change their practices based on their new understandings. Reflexive teachers are constantly in a state of development and adjust their practices based on the needs of their students.

In doing so, we hope to open further dialogue to engage more counselor educators to consider the use of self-study as a methodology to foster critical reflexivity while advocating for systemic change.

\section{Collaborative Reflective Self-Study}

It is important to distinguish the term self-study. Counselor education conceptualizes self-study as the process of examining programs by explaining how their counseling program addresses accreditation standards (Council for the Accreditation of Counseling and Related Educational Programs [CACREP], 2016). This is distinctive from the research methodology presented in this paper. Historical roots name Stenhouse, who in 1975 contended that 
professionals should be able to improve their practices through systematic research. Self-study separates itself by "focus(ing) on one's own practice and one's own role in it, and looking more deeply to identify motivations, beliefs, and concerns around an aspect of practice" (White \& Jarvis, 2019 , p. 1). Situated in the context of teacher education, self-study is a genre of research concerned with examining the role of the educator within professional practice settings. According to the Berry and Hamilton (2013, p. 1):

Self-study functions as a means of better understanding the complex nature of teaching and learning and of stimulating educational change. In self-study, researchers focus on the nature and development of personal, practical knowledge through examining, in situations, their own learning beliefs, practices, processes, contexts, and relationships. Outcomes of self-study research focus both on the personal, in terms of improved self-understanding and enhanced understanding of teaching and learning processes, and the public, in terms of the production and advancement of formal, collective knowledge about teaching and teacher education practices, programs, and contexts that form an important part of the research literature on teacher education Both personal and public purposes are concerned with the reform of teaching and teacher education that works from a social change and social justice perspective .

Overall, self-study has become an option for those "committed to the improvement of professional practice" (Loughran \& Northfield, 1998, p. 8) as it is a "powerful mechanism for reform" (Cole \& Knowles, 1998, p. 224). LaBoskey (2004) articulated the tenets of self-study methodology: "It is self-initiated and focused; it is improvement-aimed; it is interactive; [and] it includes multiple, mainly qualitative, methods" ( $\mathrm{p}$. 817). Self-study research promotes "social construction of knowledge, reflective practice, and action for social change" (Bodone et al., 2004, p. 771). This line of inquiry lends itself to counselor education, as counselor education is concerned with promoting reflective practitioners.
Two aspects of self-study appear in this work: critical friendship and communities of practice. "A critical friend acts as a sounding board, asks challenging questions, supports reframing of events, and joins in the professional learning experience" (Schuck \& Russell, 2005, p. 1). Using co-mentoring as a guide, the researchers formed a self-study community of practice centered on collaboration to better understand and improve our own practice and institutional contexts (LaBoskey, 2004; Reyes et al., 2021). We chose to use self-study to maximize the benefits for the preservice and practicing counselors and their current and future students or clients (LaBoskey, 2004) by improving our own practice. To begin our self-study, we examined ourselves in relation to context, policies, and environments where we implement our practice. Self-study acknowledges the self as the primary data source. With that, the researchers call on narrative in the form of recorded conferences and personal logs as a technique for creating objects to examine (Reissman $\&$ Speedy, 2007). In the professional logs, the researchers document critical incidents that highlight the value of explicit intentionality and the dangers associated with the lack of intentionality.

Three counselor educators engaged in self-study to further Brandon Butler's (2020) vision to extend self-study's reach beyond teacher education into multidisciplinary professions such as counselor education. The researchers embraced self-study as a scholarly way to transform professional practice. In this way, it may be a first in counselor education with multiple implications for counselor education practice in response to racism, systemic inequities, and cyclical trauma. The significance of this selfstudy lies in its creation of space for exploration and growth. While all of the researchers are committed to social justice, informed by critical race theory (Bell, 1995) and intersectionality (Crenshaw, 1989, 1991), this study illuminates growth areas that can help move our profession from conceptual and intellectual engagement to actionable, intentional, and measurable engagement. In this instance, selfstudy provides a critical opportunity to respond to our research question (Reyes et al., 2021), its subsequent follow-up questions, emergent themes, and the impact of race and racism that exists in counselor education through the lens of CRT, EST, 
and our lived experiences. According to Reyes et al. (2021), self-study methodology is a process of engaging in self-work to develop and implement change.

\section{Data Sources and Analysis Procedures}

By invitation from Brandon Butler (2020) to join a symposium, the authors met to discuss the possibility of a collaborative research project. Starting in the Fall of 2019, the research team met monthly for approximately 2 hours, with occasional texts and journal writing in between. The original intent was to complete data collection at the end of February 2020 and begin to analyze data for a presentation and publication. However, the COVID19 pandemic began, and racial disparities including the murder of George Floyd and others unfolded and ultimately impacted the entire counseling field. As a result, the research team decided to continue exploring further and continued sessions until November 2020. There were eight sessions over Zoom through the course of the year Fall 2019-Fall 2020 (excluding summer). However, it is important to note there were several other meetings that occurred to discuss the research project and process.

Each session began with a check-in regarding each other's personal and professional life. Next, the team transitioned into specific incidents related to the research question. This allowed others to comment, process, continue a line of challenging inquiry, and/or offer potential opposing views. The dialogue flowed naturally and went into more depth in each session and over time. The intent was to explore the systemic and individual challenges, successes, and personal and professional growth in attempting to disrupt the heteronormative structures inherent in counseling and the academy.

Building on qualitative research analyses, sessions were recorded and transcribed (automatically from Zoom). The transcriptions were analyzed and coded by the first and third author using thematic analysis (Braun \& Clarke, 2006), which produced six preliminary themes with the potential for 26 subthemes. The team then met to determine

Table 1. the Profession theme accuracy and provided feedback for member checking (Lincoln \& Guba, 1985). During this meeting, we intentionally acknowledged the aspects of racism, systemic oppression, and cyclic trauma at the forefront of faculty roles (e.g., teaching, supervising, service) to provide a further review of coding for themes. From there, three main themes emerged, with four subthemes. Further, a last level of analysis looked beyond content and to the process and evolution of discussions. See Table 1 for the list of final codes as well as Figure 1 for the evolution of discussion. To evidence trustworthiness, we employed LaBoskey's key characteristics that

were designed to position the researchers to produce findings that would be accepted as trustworthy. The five characteristics are 1) self-initiated and self-focused; 2) improvement aimed; 3 ) interactive at one or more points during the process; 4) the study draws from a variety of sources; 5) validity is defined as a validation process based on trustworthiness (Hawley, 2010 p. 60)

\section{Findings}

In this section, we present the research findings as an account of our shared narratives that illustrate the most salient and frequently occurring content found in our data sets, presented in the form of themes. The three main themes that emerged were intentionality in teaching, mentoring, and supervision; intentionality with program faculty and the profession; and the impact of participating in

Final Coded Themes and Subthemes from Self-Study

\begin{tabular}{|c|c|}
\hline Categories of Themes & Subthemes \\
\hline $\begin{array}{l}\text { Intentionality in Teaching, Mentoring, \& } \\
\text { Supervising }\end{array}$ & $\begin{array}{l}\text { Recruiting and Supporting Students of Color } \\
\text { Curricula \& Student Outcomes }\end{array}$ \\
\hline
\end{tabular}

Intentionality With Program Faculty and

Participation in Self-Study Impact Emotional Responses

Insights \& Questioning 
self-study. Because there are three participants, and to keep it semi-anonymous, we present quotes with session number only (e.g., session 2), as opposed to including participant (e.g., participant 2).

\section{Intentionality: Teaching, Mentoring, and Supervision}

Our analysis determined that we are intentional in how we work to facilitate equity, social justice, multicultural praxis, and attend to systemic racism (macrosystem) while trying to end the cycle of cyclical trauma visualized through the lens of CRT. Intentionality and its impacts on the mesosystem through interaction with students and faculty peers is also evident. Interaction to recruit and support students of Color, use of candor with students in teaching and mentoring, and changes we have attempted in relation to curricula provides further evidence of intentionality. Although our attempts are multifaceted in nature, there are obstacles that prevent some of the actions from moving forward that are macrosystemic. Below the finding within the subthemes are presented.

\section{Recruiting and Supporting Students of Color}

One way we are intentional about diversifying our programs is through the recruitment of and support for students from underrepresented racial, ethnic, and lingual groups. The recruitment and support observed came in two specific forms. The first is through the removal of systemic barriers to graduate education for underrepresented students (macrosystemic), which also aligns with the tenets of CRT. This includes removing standardized tests like the Graduate Record Examinations (GRE) scores due to the long-standing barriers this has presented particularly for students of Color and non-native English speakers (Sampson \& Boyer, 2001). Another way is changing the interview process, specifically, the writing component in which there was a move to assess students' commitment to social justice aspects of counseling. While gatekeeping is prevalent in counselor education (Rapp et al., 2018), this process allowed faculty to understand developmentally where students were in regard to their own reflection in power and privilege. Evidence was presented in the increase of diversity in the past and incoming cohorts of students. Although all participants admit it was not enough, as indicated by this participant, "So while it's largely still White and we've been trying to do things, we are attracting a more diverse candidate pool since removing our GRE requirement at the Masters level" (Session 1). While the successful removal of barriers was the case in two of the three participants programs and universities, it is important to note that one of the authors attempted to bring this to the forefront but was met with resistance and overruled by department faculty. Describing the incident, one participant noted, "These are White folks who can do what they want and choose how to do what they're going to do. Every time I get out voted" (Session 1). This illustrates furthering complacency in departments and maintaining status quo adding to cyclical trauma when, in fact, counseling departments should serve as protectors and guides of students and peers.

The second way we are intentional about supporting diverse students is demonstrated by building a sense of community that impacts capacity building (DePalmer, 2021) but is challenged to then support and retain students. We recognize that recruiting and supporting a diverse group of counselors would be unethical if we did not attempt to change the program and macro- and mesosystems that could and have been harmful to students of Color. Using a metaphor, one participant explain:

It's like we're going to invite more people to dinner. Inviting them to dinner doesn't mean we are going to cook the food that you like. If you have never been in my house before, I might ask if you have dietary preferences or restrictions, but it doesn't mean I will follow through. So, just because I've invited you doesn't mean you're actually going to feel comfortable with the food at my house or the music. So, inviting people to the table, meeting, to the profession doesn't mean we are actually ready. ... And if someone is brave enough and has the courage enough to say, yeah, "I am coming," even though I know some of you MFers going to say some shit to piss me off. And I am assuming the risk in coming anyway. Then, we say let's 
find another person who speaks Spanish so you can talk to them, so you don't even have to engage with me. Oh, I have done my part, and now I don't need to do anymore. And that's what happens. Black men come into the program in some way, shape or form, even though, I'm down with it because I'd rather them do that than not. Right. Typically, what happens is, oh, there's another Black person, Let's go introduce them to the only Black male educator, and he can be your advisory committee chair. It has to be me. Meanwhile, nobody else has done anything else, unless it's reflects their own values. They say, you know what, I'm going to go out of my way to make sure this student is comfortable at my house with this food. And while they are here, I'm actually going to try to engage with him so that I can learn a little bit more about what makes him comfortable and feel confident in this space where he might be in the numerical, ethnic, whatever socioeconomic minority. But that's what we do. We say, come on, come over here and then don't do shit. And if we do something and it's like, well, let me point it to the people who are like you from what I know or can visibly see. Yeah, but that's pathetic. That's generally what happens. And so, while it's cool that the more invitations are being sent out and being extended and people are accepting those invitations, it doesn't mean that we still don't have work to do to make the climate more welcoming, safe, and affirming for one thing. Our students of Color on my campus are very clear. They don't trust White people. Right. Like years of not trusting White people. What makes you think right now as a masters/doc student you will be the first one? (Session 2)

Therefore, through programming, we intentionally build a sense of community interacting with the exosystem to mitigate the potential environment for counseling students, in the hopes to meet some of the unique needs that racially and ethnically diverse students possess as graduate students. We attempt to do this collectively through strategic mentoring, using brutally honest candor in student interactions (i.e., large group, advising settings, individually, and supervision [individual, triadic, and/or didactic]), giving attention to classroom and mentoring norms, creating groups specific to the unique needs of students of Color, and modeling inclusivity through language and availability. We also connect students to other support resources and opportunities such as monthly program newsletters, listening to student voices, assessing program climate, using student voice to advocate for change, and creating curricula experiences that foster inclusivity while challenging the status quo. This action attends to interactions at the macro-, meso-, and microsystemic levels. What is missing from many systems is an attention to race and its overarching impact.

\section{Curricula and Student Outcomes}

Building on creating a sense of community, we work to facilitate equity, social justice, and multicultural praxis by building in and out of classroom experiences that foster development. In the classrooms, we intentionally shape students' curricular (macro) experiences (micro) to learn from each other about diverse clients. One example is addressing privilege and implicit bias early in the first semester for counseling students. Collectively, we have all had different experiences. For one participant describing intentionality in a techniques class:

They really struggled with broaching differences, talking about diversity or being different from the person or sitting across them, whether it is based on gender, ethnicity, spiritual beliefs. And, you know, this is after in-depth discussions that we had in class. (Session 1)

In contrast another participant found other students a little more ready:

I see some evidence of it, but at least in my experience, students are a little bit further along in their willingness to say, you know what? I'm a White woman and I know I'm going to be working with Black and Brown children in elementary school. And I know that, and I know I look entirely different from everybody in this building. So, let's just start there. (Session 1) 
In using intentionality in the classroom, we are attempting to break down assumptions from day one that students hold of future clients, stakeholders, and the profession. Sometimes, that has multiple outcomes. When one participant questioned the abrasiveness of their intentionality, another participant responded:

I begin my class telling them I want to learn more about you, and I'll share more about myself, but let's get right to work. And I literally get the whiteboard. I get some dry erase markers, and I put the word students at the bottom of the whiteboard. I want you to put on this whiteboard to the extent you're comfortable getting up. Everybody's not required to get up. But if you're inclined to get up, I want you to write all of the influences on you as a school counselor delivering services to the students. And I want you to put the names of those influences in proximity to the name students at the bottom. They put teachers and principals. And so, this word cloud begins to form. Well, they never put state legislation, rarely put federal legislation. They rarely put the department, the secretary of education. They rarely put the president. They rarely even put like the mayor or even your district policy. Oh, come on. Right. So, we really began filling in all these gaps. And I'm like, when it's all said and done, we've got this kind of nice word cloud. And I was like are you sure you still want to be school counselor?

Because these are all the influences that are going to have. These are all the variables that influence your ability to do this work. This is not you just doing individual counseling with kids, you have to navigate all these points. Superintendent, assistant super, dismissive teachers. Yeah. So, you begin to ask questions about the patterns in your school. So who is or isn't an honors classes? Who keeps getting suspended and who doesn't? And then I ask, you sure you still want to do this? You know, so I think you absolutely are spot on by being able to give that tone right away because you'll begin to find out who can hang. (Session 3)
The above-mentioned quote highlights the direct candor and intentionality used upfront with students. Another participant echoed the same tactic and indicated:

Look, I need you to realize we're teaching you the ideal. Guess what? School counseling was built for White, affluent people. Guess who's in schools? Not only that right? So, if today's schools are still operating the same way they did when the one room schoolhouse started, who's benefiting from it? And in your job, you might ultimately end up having to challenge that in order to meet the needs for the students who are in front of you. And that means that you might be the only person in the building who will be willing to take a stand and do something about it. And are you willing to do it? (Session 5)

However, sometimes, the outcomes have other consequences:

This is becoming a pattern in class. We are doing a lot of processing in our intro courses on systemic oppression or looking at equity issues. I have students of Color who grew up in predominantly White spaces, and this never occurred to them. So, there is a lot of emotion in "waking up." Watching the process alongside White students is hard, as I am not sure they get that level of emotion in the same way. (Session 5)

These outcomes further the importance of the reflective process for counselor educators and a parallel process for our students. The ability to engage in-depth with intention in our classes is further evidence of our intentionality in creating a safe space and community.

While we reflected on our intentionality, we feel like we have not been as successful regarding counseling theories (macro). Unanimously, we agree that our programs are beginning to include more culturally relevant theories but still have not eliminated the historical theories that are no longer relevant but may be required on licensure exams and required by accreditation bodies (i.e., CACREP). Additionally, we all have doctoral programs and discussed integrating relational 
cultural theory (Jordan, 2017) into supervision as a means of addressing postmodern supervisory needs.

While we are able to be more intentional in our classroom spaces, in each of our programs, we advocate for mixed fieldwork supervision experiences in the hopes that students develop a unified professional counselor identity while learning about client needs in diverse treatment settings across systems (e.g., school counseling, student affairs, clinical mental health, addictions). Outside of the classroom, we encourage immersion experiences beyond the multicultural counseling and/or field experience classes. These immersion experiences are designed to directly challenge stereotypes and misconceptions about people from systematically disinvested communities, people of Color, and other minoritized people.

\section{Intentionality With Program Faculty and the Profession}

We understand that disrupting systemic racism and cyclical academic trauma for minoritized students extends through advocacy at the program, department, college levels, and across the profession through service, which are macrolevel systems interactions that further impact the microand mesosystems through relational interactions. One way we enact these practices is through being consistently vocal and reflective about our own minoritized status as faculty. Often, this practice comes at the cost of being outnumbered and made to feel invisible or hypervisible based on our racial, gender, and/or affectional orientation identities. As a result, the burden is still placed on minoritized faculty to challenge peers, as evident by this participant:

Some faculty of Color, including me. We're just like Google what we're doing, because right now we can't, we can't even say Brianna Taylor's name in the, in the context of a faculty meeting. So, that kinds of put everybody on the defensive and then there seem to be all this energy toward equity work and like what are we supposed to do now? Want to take the lead? Unfortunately, because this stuff is so near and dear to mine and other folks' heart, we begin to make suggestions, but we're people of Color doing this right? (Session 5)
In addition, there is a blind spot for White faculty about the impact of this year by the many racial disparities, examples of racism, and the murdering of Black people.

In this entire time, short of these conversations, I finally had a White person say after seven months, keeping in mind we are in a counseling profession that teaches empathy, and I am a black male with five biracial children, "I wonder what it must be like for you?" First White colleague to ask." (Session 6) In response, another participant responded, "I'm trying to think of any White colleague that has actually done a, like a check in with me personally. I can't think of any" (Session 6).

Another participant responded:

But I don't know, even if we were thinking about sharing a workload balance for burden with each other. This is just so fundamental to who we are as human beings, and then a profession, and yet, how are we supposed to ever to a point where we have made progress, if we can't even see the person in front of us and keeping in mind that sure everyone's in crisis, but how do you not recognize that people are in a different places space of crisis? " (Session 6)

This just further exemplifies that White privilege permeates the department and the program, even when it comes to expectations centered around equity work. Although we continue to advocate, it is still causing the same cyclical academic trauma we are trying to disrupt, and it is visible by master's level and doctoral students, who report feeling validated and seen and are willing to take risks but also are recipients of secondary trauma by bearing witness the continued microaggressions and slow progressive movement.

Beyond our universities, we are all active leaders in the counseling profession at the state, regional, and national levels engaging in numerous service obligations through both scholarship and service. We are intentional about service as we recognize there needs to be a voice at multiple levels to advance the profession forward. As one participant points out, "I've been elected and appointed to some position. So, I would consider myself like somebody who's trying to disrupt it" (Session 6). Sometimes, that intentionality also leaves us with a 
multitude of barriers and feelings. As one participant mentions:

Black males is, and particularly among folks of Color and particularly specifically among Black men. There's an old guard in the new guard right now actively mentor and shepherd folks into positions and to gain the influence that they want, particularly students of Color and faculty of Color. I believe there are some in the old guard. I'm talking specifically about Black men who still want to acquiesce to Whiteness. That's their preference. That's their safety, as I'm not as sensitized to acquiesce and to Whiteness, even though I'm guilty of it at times, and I definitely have. And definitely can be nonconfrontational times and things like that. But the outcome may be more complacency than progress. So we, the new guard, run for office to forward progress. (Session 7) In response, another participant indicates: I agree that leaves people like [Participant] to say, I want to run for this office in this association. And then when you get there, we gonna do a little speaking truth to power about the lack of diversity within our leadership. So, me not feeling like I had a voice to insert at the front of the line. I was learning. And so that's what I mean by deference, deference to people who I've read and what they say they've been doing in this profession, in these areas around multicultural issues and social justice blazers.

(Session 6)

We recognize there are many levels to leadership, and it does not have remain in the traditional counseling professions and can expand to other organizations like the Association of African Americans in Counseling and the Black Mental Health Symposium to promote professional identity and progressive leadership. However, we also recognize that in doing this this fragments the counseling profession further than it already is and may seem like complacency, perpetuating Whiteness, or causing harm as opposed to finding ways to thrive in a profession that continues to cause cyclical trauma for minoritized individuals.

\section{Participation in Self-Study Impact}

Participating in this research endeavor elicited many feelings and emotions and responding coping skills that were captured through the sessions while also leaving us questioning our own work and hope for the counseling profession. Overall, we participated in a bottom-up process versus one that is top -own. We engaged in relationship where reciprocity was constant. In addition, it was grounded in our attendance to race (CRT) as an immovable construct that impacts all of what we experience.

\section{Emotional Responses and Coping}

Our elicited emotional responses (micro) to processing these experiences include, but are not limited to, hope, fatigue, doubt, defeat, imposter syndrome, internalized oppression, indifference, feeling jaded, mistrust, apathy, and complacency. What came to bare was that this was an interaction of our values (DePalmer, 2021) both individual and shared. While we all build boundaries for coping and action to give hope, the struggle is real to balance that against racism and cyclical trauma. In reflecting on being in a safe space professionally and in attempt at survival one member describes:

It's literally to me demonstration of internalized oppression. Like you just begin. You begin to take on and subscribe to the values of the systems around you. And it's hard not to. Make no mistake, it's hard not to buy into the to the shit we know when you're in it all the time. And so I can only imagine like, you know, a coop at some point. And survive. You actually start to believe even if you don't actively say I believe that you actually believe that we are making progress that we are making. You actually might start to believe, hey, it's not as bad as people say it is at work. (Session 7)

While we found these professional conversations enlightening, we were also very clear about our personal boundaries and commitment to continued wellness. All three of us use nature and exercise through walking and biking, regardless of the weather, that help center us and keep us from work trauma and fatigue. Additionally, we all have 
children who facilitate a natural boundary for time and space, specifically during the pandemic. However, due to the structures of our families, it also propels us to do more professionally on behalf of our families and others like them who have traditionally been oppressed. It is still a balancing act and remains a continuous struggle.

\section{Insights and Questioning}

On reflection, these sessions mirrored peer supervision in how we supported and challenged our professional identities as counselor educators, mentors, and leaders. As a result, it left us with numerous self-reflective questions and insights (micro) as we think about progressing forward. All three of us questioned our roles and places in counselor education. For example, one participant started a dialogue, "Do I still want to do this? Yeah. Like in or out? And if it's in, what does it look like and if it's out? It's like all the way out, out, out, out? (Session 8)

Another participant inquires,

Well, I've actually had to ask myself the question, is this what I'm supposed to be doing? Like, is this a natural evolution? Like, I do this for a while and then I transition into some better version of this or a different version of this, or do I leave this? When I got promoted and tenured, I said to myself, I might take a year off and not physically because I couldn't afford it. But I was going to take some time to do a lot, a lot less writing, you know, reduce some of my commitment so I can really do an assessment of like, who am I in this profession? What do I want to devote my professional energy to, and then do those things. But the pandemic hit, and who had time to question that? And then the question is, can I really live with myself by not trying to address racism at this moment when it needs to be continually amplified nationally, but more importantly in our profession? And can I work with others who are not committed to this? (Session 8)

A colleague responds:

Well, that's the thing, right? Everybody can only do their part right now in the space that you have. I guess for me I'm trying to figure out how I attend to everything right now.
And as you know, I actually more tend to the mental health side of it, by way of advocacy, because if I were going to that meeting, what you just described would have never been part of my conversation. Right. Even though it's still identity. So, I really need to figure that out for myself. (Session 7)

While questioning can lead to further action and processing, it also left us with some powerful insights for ourselves and hopes and fears for the profession. One fear about counselor education in particular around school counseling is summed up by the following:

We're going to be so split, and we are already divided counselor ed, and now we're going be a further divide in a school setting similar to what you're describing, where we need addictions and really true clinical mental health assistance, all of those things. And if we don't get it together in general ourselves, then all the other fields like social work and psychology are going to step in as opposed to the counseling profession. Now is the time to have a wakeup call. Either our profession makes a stand now, or we become obsolete in schools. (Session 8)

Although the sessions and dialogues were raw and elicited honest responses, there was a sense of overall comradery and care and concern for each other. To summarize one participant describes, "Overall, in our time together, I feel I have an opportunity to expand my thought horizons, challenge my apathy at times or inaction" (Session 7). The entire team echoed similar sentiments that the overall process was helpful and provided an opportunity for honest introspection to ourselves and roles we play in confronting racism, systemic oppression, and cyclical trauma in counselor education, as well as a coping skill through critical friendship and an established community of practice.

\section{Self-Study Stages and Process}

Our community of practice (micro) not only mirrors peer supervision but also presents similar to the stages of group process (Corey et al., 2018), where members progress from an orientation stage and surface level talk, to the working and actionoriented stage, to a termination phase. For us, the orientation stage consisted of defining diversity and 
discussing the shades of diversity we are witnessing in our programs and also with our children in their educational experiences. This led toward a deeper conversation about the experiences we have had in the past and now in the current climate surrounding the pandemic with conditioning and academic trauma for diverse students. That conversation led to us discussing our own academic trauma as a minoritized faculty member. As a result of those shared stories, we moved to a working stage, and it allowed us to examine and share how we are intentional across multiple contexts in confronting racism, systemic oppression, and cyclical trauma. There is a realization that the work we engage in confronts racism, but we are unsure how our work is contributing to disrupting systemic oppression in the way we would envision. This led to some real work on questioning and challenging one another in this area. As we moved toward the termination phase, we were able to process and share emotional responses, things we are still questioning about ourselves and the profession, and brainstorm some directions for allotting our energy in this longstanding battle. Overall, it was a cathartic experience that also added a layer of accountability for committing to this work.

[Insert Figure 1]

\section{Discussion}

The findings from this self-study are useful as they align and compliment reports of prior publications that address how counselor educators work to actively identify and disrupt norms that marginalize members of the profession at every level (e.g., as students, practicing counselors, counselor educators). We endeavored to learn what happens within us and for us when we intentionally and consistently raise issues of race, systemic oppression, and cyclic trauma within our counseling communities, institutionally and beyond. Our discussion will focus on how this intentionality was/is personally transformative and has the potential to be transformative within the profession in the context of the findings previously mentioned. These ends speak to the aims of self-study highlighted by Berry and Hamilton (2013), who wrote that self-study research outcomes focus on both the personal (e.g., self-understanding, enhanced understanding of teaching, and learning processes) and the public (e.g., production and promotion of knowledge about teaching and teacher education practices, programs, contexts, etc.).

\section{Intentionality Across Contexts}

Participating in this self-study raised our collective awareness about the value of intentionally broaching racism and other forms of oppression in our teaching, supervision, and service as counselor educators. Unfortunately, little to nothing exists in our accreditation standards (CACREP, 2016), our best practices in teaching report (Association for Counselor Education and Supervision [ACES], 2016), or other profession-wide resources that speak to confronting systemic oppression within counseling programs. We might highlight the Multicultural and Social Justice Counseling Competencies (Ratts et al., 2016) as one resource on how to fight systemic oppression in our programs, but it is primarily constructed to assist practicing counselors in working with clients. There is very little in the literature that makes recommendations on how programs, from a systemic perspective, can disrupt the different forms of oppression they enact on members of their individual programs implicitly or explicitly. This phenomenon could be described as oppressive because it leaves the assessment of climate and functioning to their individual programs' motivation and dedication to eliminating the oppression that we enact on students, faculty, and staff of counseling programs.

For example, our identified theme of recruiting students of Color are specific metrics that counseling programs can use to analyze the ways they are disrupting oppressive norms that are racist and traumatizing. The recruitment and retention of racially and culturally diverse students and faculty continues to be a systemic challenge for counseling programs. In its last report of disaggregated enrollment demographic data, CACREP (2017) reported that White students comprised approximately $60 \%$ of close to 46,000 enrolled counseling students, whereas Black students (approximately 20\%) and Hispanic/Latino students (approximately 9\%) made up the majority of remaining students. Self-identified multiracial, Asian American, Indigenous, and Other/Undisclosed students comprised the 
remaining $11 \%$ of other enrolled students. The racial disproportionality is even greater among counselor education faculty, as indicated in the same CACREP (2017) report. White faculty comprised approximately $74 \%$, or 1,850 of the close to 2,490 faculty in counseling programs. Black faculty represented approximately $12.5 \%$, followed by Hispanic/Latino faculty (4.8\%) and Asian American faculty $(3.3 \%)$. The remaining racial groups, including Multiracial, Asian American, Indigenous, and Other/Undisclosed, comprised the rest, amounting to just approximately $7 \%$. What is unknown is how much these trends have changed since the publication of the 2017 report, given CACREP has stopped publishing these data. These data points provide a sobering example of why CRT is a valuable lens to further assess the state of the counseling profession.

Our individual efforts to recruit students of Color was evidenced by being visible and active in recruitment (e.g., open houses, information sessions) and critiquing our individual programs' commitment to developing climates that are attractive to students of Color and those from other underrepresented groups in counseling. The profession has not experienced a system-wide call to action, from the American Counseling Association and/or any of its sister divisions, accreditation and credentialing bodies (e.g., CACREP, National Board of Certified Counselors) to reduce such disparities. Similarly, no state licensing boards or bodies have actively called on counseling programs to take affirmative action to reduce them either. Similarly, no state licensing boards or bodies have actively called on counseling programs to take affirmative action to reduce them either. This point is critical given what research continues to tell us about how diverse clients have inequitable access to nonbiased treatment within mental health care (Cook et al., 2017; Noonan et al., 2016; Primm et al., 2010), although clients of Color prefer counselors of Color for treatment (GoodeCross \& Grim, 2014). Our individual efforts in these areas reflect contributions of service from a programmatic standpoint. However, there were also considerations for the relationship between our individual teaching and supervision efforts as compared with programmatic values that inform those teaching efforts.
For example, it is reasonable to infer that some counseling programs go beyond accreditation compliance of offering one course on the influence of social and cultural diversity in the counseling process. It is likely that many programs make explicit decisions to integrate the importance of social and cultural diversity across all required courses (e.g., Introduction to the Counseling Profession, Human Growth and Development, Legal and Ethical Issues, Group Counseling). As participants, we learned about our individual teaching and supervision practices of actively centering racism and other forms of oppression in every course we teach. That is, we address questions like how did/does racism influence the evolution of the counseling profession? How does racism and other forms of marginalization influence individuals' growth and development across the life span? How does racism influence the assessment and diagnosis process (if applicable) in the counseling process? But, how counseling programs do this systemically is a question that has been left unanswered, leaving the possibility of our enacting of racism, oppression, and trauma on community members open and likely. The content above is highlighted by what Berry and Hamilton (2013) describe as the personal outcomes of self-study research. What follows is the public outcomes of self-study research (Berry \& Hamilton, 2013), with a set of recommendations for counselor education and recommendations for research.

\section{Recommendations for Counselor Education}

We contend that counselor education (i.e., counseling programs; accreditation, licensing, and certification bodies; associations) can benefit from acting on specific recommendations that can actively and unapologetically reduce the harm they may be causing to counseling students, practitioners, and faculty. We acknowledge this list is not comprehensive, yet, can be the beginning of moving our profession, and the programs therein, to meet its articulated ideals. Our first recommendation is for our organizations to acknowledge their role in harming individuals and communities through the lens of CRT (Crenshaw et al, 1995) and EST (Bronfenbrenner, 1979, 2001, 2005). Counseling associations and our accreditation and certification bodies have yet to 
acknowledge their complicit role in marginalizing specific groups of people because of race, socioeconomic status, and other forms of identity. A formal acknowledgment to counseling association membership that assumes responsibility for exclusion and marginalization is critical to developing action plans to reduce further harm. This exclusion is evidenced by the overwhelmingly and persistent White power structure and systems that exist in our associations via elected and appointed positions, eligibility criteria for said elected and appointed positions, and other ways the overwhelmingly White membership continues to exert its influence and preference for a White power structure.

Our second recommendation is actualized in at least two steps. We recommend counseling programs take affirmative action to increase the racial, cultural, and linguistic diversity of its students and faculty. We recommend they enact initiatives to continually assess their programs' climates to meet a specific set of measurable, attainable, realistic, and time-sensitive goals. This can take the form of setting goals to recruit underrepresented students from historically and/or predominantly Black colleges, Hispanic serving institutions, and/or tribal colleges and universities. The second part of this recommendation includes administering annual program climate surveys to students, faculty, and staff to assess how people are experiencing their programs in various ways and using these data as a way to inform how programs evolve and transform to better meet their stakeholders' needs (Hannon et al., 2019).

One final recommendation for counselor education is curricular. Given CACREP and state licensing bodies have not required programs to take an active, public, or vocal stance against oppressive norms that may exist in counseling programs, it is up to individual programs to assess their own values to actualize their anti-oppressive and anti-racist positions in their respective curricula. One way this can happen is by program and department chair people requiring faculty to include in their syllabi the ways learning experiences are designed to acknowledge, challenge, and disrupt norms that prioritize Whiteness, straightness, Christianity, and other forms of structural oppression in the curricular learning experiences for students.

\section{Limitations}

There are inherent limitations with self-study. One limitation suggested by Loughran and Northfield (1998) is that collaborative reflection may simply reiterate communally held prejudices and attitudes unless explicit processes are set in place to question perception from divergent perspectives. This limitation is ideally addressed in our recommendations documented previously. A second methodological limitation is the value of a broader and wider representation of counselor educators and/or programs who are actively working against their own oppressive norms. Case studies of counseling programs, in particular, would assist in deepening the knowledge base about how programs are working to disrupt marginalizing practices and norms.

\section{Conclusions}

Our paper aimed to help initiate critical discourse and subsequent action against the heteronormative and racist structures in counselor education we have experienced while confronting personal and professional challenges and systemic barriers to cultivating the value and agency of anti-racism in counselors and educators. This self-study provided the opportunity for the three of us to study our intentionality in teaching preservice counselors to promote equity, justice, and multicultural praxis while acknowledging, resisting, and disrupting systemically racist practices and preventing cyclical academic trauma. We used personal logs and recorded conversations to document narrative accounts of critical incidents toward this end. Our initial insights indicate that the profession could benefit from a range of action items that include but are not limited to our profession acknowledging the harm it has inflicted on marginalized communities, our programs taking affirmative action to address disparities in enrollment and faculty demographics, and making curricular changes to affirm their professed value in an anti-oppressive and anti-racist ethos. These are the early steps in reconciling our profession's marginalizing history and chartering its future. 


\section{References}

American Counseling Association. (2014). ACA code of ethics.

Association for Counselor Education and Supervision. (2016). ACES teaching initiative taskforce: Best Practices in teaching in counselor education.

Bell, D. (1995). Who is afraid of critical race theory? University Law Review, 4(1), 893-910.

Becker, A., \& Todd, M. (2018). Watching the evolution of the American family? Amazon's transparent, ecological systems theory, and the changing dynamics of public opinion. Journal of Homosexuality, 65(9), 1120 1137. https://doi.org/10.1080/00918369.2017.1406212

Berry, A., \& Hamilton. M. L. (2013). Self-study of teacher education practices. Oxford bibliographies in education (pp. 1-3). Oxford University Press.

Bodone, F., Guojónsdóttir, H., \& Dalmau, M. C. (2004). Revisioning and recreating practice: Collaboration in self-study. In International handbook of self-study of teaching and teacher education practices (pp. 743-784). Springer.

Braun, V., \& Clarke, V. (2006). Using thematic analysis in psychology. Qualitative Research in Psychology, 3(2), 77-101. https://doi.org/10.1191/1478088706qp063oa

Bronfenbrenner, U. (1979). The ecology of human development: Experiments by nature and design. Harvard University Press.

Bronfenbrenner, U. (2001). The bioecological theory of human development. In N. J. Smelser \& P. B. Baltes (Eds.), International encyclopedia of the social and behavioral sciences (vol. 10, pp. 6963-6970). Elsevier.

Bronfenbrenner, U. (2005). Making human beings human: Bioecological perspectives on human development. British Journal of Developmental Psychology, 23(1), 143-152. https://doi.org/10.1348/026151004X21134

Bronfenbrenner, U., \& Evans, G. W. (2000). Development science in the 21st century: Emerging questions, theoretical models, research designs, and empirical findings. Social Development, 9(1), 115-125. https://doi.org/10.1111/1467-9507.00114

Butler, B. (2020). How can we extend self-study scholarship (and why might we want to)? Symposium accepted to the Self-Study SIG at the American at the American Education Research Association Annual Conference. [Cancelled due to COVID-19]

Cole, A. L., \& Knowles, J. G. (1998). The self-study of teacher education practices and the reform of teacher education. In M. L. Hamilton (Ed.), Reconceptualizing teaching practice: Self-study in teacher education (pp. 224-234). Routledge.

Cook, B. L., Trinh, N. H., Li, Z., Hou, S. S., \& Progovac, A. M. (2017). Trends in racial-ethnic disparities in access to mental health care, 2004-2012. Psychiatric services (Washington, D.C.), 68(1), 9-16. https://doi.org/10.1176/appi.ps.201500453

Cooke, N. A. (2019). Impolite hostilities and vague sympathies: Academia as a site of cyclical abuse. Journal of Education for Library and Information Science, 60(3), 223-230. https://files.eric.ed.gov/fulltext/EJ1222873.pdf

Corey, M. S., Corey, G., \& Corey, C. (2018). Groups: Process and practice (10th ed.). Cengage Learning.

Council for the Accreditation of Counseling and Related Educational Programs (2016). CACREP standards. Council for Accreditation of Counseling and Related Educational Programs. (2017). Annual report 2016. http:// www.cacrep.org/wp-content/uploads/2019/05/CACREP-2016-Annual-Report.pdf

Crenshaw, K. (1989) Demarginalizing the intersection of race and sex: A Black feminist critique of antidiscrimination doctrine, feminist theory, and antiracist politics. University of Chicago Legal Forum (1), Article 8: 138-167.

Crenshaw, K. (1991). Mapping the margins: Intersectionality, identity politics, and violence against women of Color. Stanford Law Review, 43(6), 1241-1299.

http://bostonreview.net/archives/BR16.6/crenshaw.html

Crenshaw, K., Gotanda, N., Peller, G., \& Thomas, K. (1995). Critical race theory: The key writings that formed the movement. New Press.

Delgado, R. (1995). The imperial scholar: Reflections on a review of civil rights literature. In K. W. Crenshaw , N. Gotanda, G. Peller, $\&$ K. Thomas (Eds.), Critical race theory: The key writings that formed the movement (pp. 46-57). New York: New Press

DePalmer, S. (2021.) An interpretative phenomenological analysis of school counselor intraprofessional collaboration: How school counselors work together in the name of comprehensive programming [Unpublished doctoral dissertation]. Shippensburg University.

Goode-Cross, D. T., \& Grim, K. A. (2014). “An unspoken level of comfort": Black therapists' experiences working with Black clients. Journal of Black Psychology, 42(1), 29-53. https://doi.org/10.1177/0095798414552103

Hannon, L. V. (2019). Engaging my whole self in learning to teach for social justice: Where my loyalties lay. In J. Kitchen (ed.), Second International Handbook of Self-Study of Teaching and Teacher Education, Springer International Handbooks of Education (pp. 737-762). Springer. https://doi.org/10.1007/978981-13-1710-1 25-1

Hannon, M. D., Nadrich, T., Ferguson, A. L., Bonner, M. W., Ford, D. J., \& Vereen, L. G. (2019), Contributing factors to earning tenure among Black male counselor educators. Counselor Education and Supervision, 58(2), 82-97. https://doi.org/10.1002/ceas.12133

Hawley, T. S. (2010). Self-study methodology as a means toward ongoing rationale development and refinement. In A. R. Crowe (Ed.), The power, promise, and use of self-study in social studies education (pp. 55-70). Springer.

Ieva, K. P., Beasley, J., Steen, S. (2021). Equipping school counselors for antiracist healing centered groups: a critical examination of preparation, connected curricula, professional practice and oversight. Submitted to a special issue of Teaching and Supervision in Counseling, 3(2), 64-78.

Jordan, J. V. (2017). Relational-cultural therapy (2nd ed.). Washington, DC: American Psychological Association.

LaBoskey, V. K. (2004). The methodology of self-study and its theoretical underpinnings. In J. J. Loughran, M. L. Hamilton, V. K. LaBoskey, \& T. Russell (Eds.), International handbook of self-study of teaching and teacher education practices, Vol. 1 (pp. 817-869). Springer.

Lincoln, Y. S., \& Guba, E. G. (1985). Naturalistic inquiry. Newbury Park, CA: Sage.

Morettini, B., Brown, C., Perry, J., \& Ieva, K. P. (2018). Navigating heteronormative structures: how four transdisciplinary faculty used a self-study community of practice to reflect on enacting a social justice stance. Paper presented at the American Education Research Association Annual Conference, Toronto, Canada.

Loughran, J. J., \& Northfield, J. (1998). A framework for the development of self-study practice. In M. L. Hamilton (Ed.), Reconceptualizing teaching practice: Self-study in teacher education (pp. 7-18). Routledge.

Nadrich, T., (2019). The lines between the checkboxes : The experiences of racially ambiguous people of color. Theses, Dissertations and Culminating Projects, 306. https://digitalcommons.montclair.edu/etd/306

Noonan, A. S., Velasco-Mondragon, H. E. \& Wagner, F. A. (2016) Improving the health of African Americans in the USA: An overdue opportunity for social justice. Public Health Review, 3712, Article 12. https://doi.org/10.1186/s40985-016-0025-4

Teaching and Supervision in Counseling * $2021 *$ Volume $3(2)$ 
Picower, B. (2012). Practice what you teach: Social justice education in the classroom and the streets. Routledge.

Primm, A. B., Vasquez, M. J., Mays, R. A., Sammons-Posey, D., McKnight-Eily, L. R., Presley-Cantrell, L. R., McGuire, L. C., Chapman, D. P., \& Perry, G. S. (2010). The role of public health in addressing racial and ethnic disparities in mental health and mental illness. Preventing Chronic Disease, 7(1), A20.

Rapp, M. C., Moody, S. J., \& Stewart, L.A. (2018). Becoming a gatekeeper: Recommendations for preparing doctoral students in counselor education. Professional Counselor, 8(2), 190-199.

Ratts, M.J., Singh, A.A., Nassar-McMillan, S., Butler, S.K., \& McCullough, J.R. (2016), Multicultural and social justice counseling competencies: Guidelines for the counseling profession. Journal of Multicultural Counseling and Development, 44(1), 28-48. https://doi.org/10.1002/jmcd.12035

Reyes, G., Aronson, B., Batchelor, K. E., Ross, G., \& Radina, R. (2021). Working in solidarity: An intersectional self-study as a means to inform social justice teacher education. Action in Teacher Education. https://doi.org/10.1080/01626620.2021.1883149

Riessman, C. K., \& Speedy, J. (2007). Narrative inquiry in the psychotherapy professions. In J. Clandinin (Ed.), Handbook of narrative inquiry: Mapping a methodology (pp. 426-456). Sage.

Sampson, C., \& Boyer, P. G. (2001). GRE scores as predictors of minorities' success in graduate study: An argument for change. College Student Journal, 35(2), 271.

Schuck, S., \& Russell, T. (2005). Self-study, critical friendship, and the complexities of teacher education. Studying Teacher
Education, 1(2), 107-121.

Singh, A, Appling, B, \& Trepal, H. (2020). Using the multicultural and social justice counseling competencies to decolonize counseling practice: The important roles of theory, power, and action. Journal of Counseling and Development, 98, 261-271.

Smith, J. A., \& Osborn, M. (2015). Interpretative phenomenological analysis as a useful methodology for research on the lived experience of pain. British Journal of Pain, 9(1), 41-42. https://doi.org/10.1177/2049463714541642

Steen, S., Vandetta, R., Ieva, K. P. (unpublished manuscript). Introduction to culturally sustaining group counseling: An inclusive framework. Springer Publishing: New York, NY.

Stenhouse, L. (1975). An introduction to curriculum research and development. Heineman.

Yancy-Bragg, N. (2020 June 15). What is systemic racism? Here's what it means and how you can help dismantle it. USA Today. https://www.usatoday.com/story/news/nation/2020/06/15/systemi c-racism-what-does-mean/5343549002/

United States Census Bureau (2018). American community survey 5year estimates. Retrieved from https://datausa.io/profile/soc/counselors\#employment

Villalpando, O. (2003). Self-segregation or self-preservation? A critical race theory and Latina/o critical theory analysis of a study of Chicana/o college students. Qualitative Studies in Education, 16(5), 619-646.

White, E., \& Jarvis, J. (2019). Self-study: A developing research approach for professional learning. LINK-University of Hertfordshire. 